Всесвітня історія

\section{Recent history}

ISSN: 2411-6181(on-line); ISSN: 2311-9896 (print)

Current issues of social studies and history of medicine. Joint Ukrainian -Romanian scientific journal, 2019, №:2(22), P. 46-50

UDK 327(438):[351.863:620.9]

DOI 10.24061/2411-6181.2.2019.114

\author{
ПОЛЬЩ \\ Олег СЛЮСАР \\ Чернівецький національний університет \\ імені Юрія Федьковича, Чернівці (Україна) \\ o.slusar@chnu.edu.ua
}

СТАН ТА ПРЕСПЕКТИВИ ЕНЕРГЕТИЧНОЇ БЕЗПЕКИ

\author{
THE STATE AND PROSPECTS OF POLAND'S ENERGY \\ SECURITY \\ Oleg SLIUSAR \\ Yuriy Fedkovych Chernivtsi National University, Chernivtsi (Ukraine) \\ ORCID ID: 0000-0002-1382-3394; Researcher ID: S-5743-2016
}

\begin{abstract}
Слюсар О. Состояние и перспективы энергетической безопасности Польши. Цель исследования. В статье проанализировано сегодняшнее состояние энергетической безопасности Польши, указано на значительный потенциал атомной энергетики, состояние развития электроэнергетики на основе возобновляемых источников энергии, их экономические составляющие, а также влияние энергетической безопасности на будущее государства и перспективы развития этой отрасли промышленности. Анализ даной проблематики обусловил использование следующих методов исследования, среди которых экономический анализ сделал возможным исследование себестоимости производства киловатта энергии, поставляемой электростанциями; метод теоретического анализа в сочетании с практическими подсчетами позволили установить целесообразность строительства ядерных электростанций в Польше, а также потребность диверсификации поставок природного газа для уменьшения зависимости этого государства от Российской Федерации. Научная новизна. Впервые детально проанализировано ядерный потенциал Польши и зависимость от этого фактора энергетической безопасности государства. Выводы. Проведенный анализ свидетельствует о необходимости строительства атомных электростанций для обеспечения устойчивого развития и энергетической безопасности Польши.

Ключевые слова: энергетика, энергетическая безопасность, ядерная энергетика, возобновляемые источники энергии, диверсификаиия поставок.
\end{abstract}

Постановка проблеми та їі зв'язок із важливими науковими завданнями. Енергетична безпека держави $\epsilon$ багатовекторним поняттям і стосується багатьох явищ та процесів в енергетиці, економіці, зовнішній та внутрішній політиці даної країни. Енергетична безпека - це також здатність державних органів забезпечити кінцевих споживачів енергією в необхідному обсязі та належної якості в надзвичайних умовах.

Періодичні стрибки зацікавлення справами енергетичної безпеки викликані, в значній мірі, ростом попиту на нафту і цін на цю сировину, збільшенням кількості терористичних актів та, загалом, тероризму, політичною нестабільністю регіонів, з яких постачають цю сировину, геополітичними трансформаціями, а також зростаючим попитом на енергію економік, що розвиваються, а саме, Китаю та Індії. Тому, протягом останніх десятиліть, стало ясно, що концепцію енергетичної безпеки необхідно розширити на два ключові аспекти, пов'язані 3 необхідністю розглядати енергетичну безпеку в глобальному масштабі.

Одним 3 найістотніших викликів, сьогодення стає боротьба за корисні копалини, які є сировинною базою для енергетичної галузі. Заслуговує на увагу, перед усім, боротьба Китаю та держав Заходу за нові поклади корисних копалин та впливи, від яких залежить видобуток, як розвіданих, так і перспективних родовищ.

Енергетичну безпеку найкраще розглядати зі сфери управління ризиком, тобто мінімізації ризиків та зменшення перебоїв в поставках до прийнятного рівня. Одночасно ризик, пов'язаний з утриманням енергетичної безпеки можна поділити на коротко- і довготерміновий.
Короткотерміновий ризик пов'язаний з наслідками цінової шокової терапії та непередбачуваних затримок в поставках, викликаних аваріями, тероризмом, екстремальними погодними умовами чи аваріями мереж поставок. Також його називають операційним ризиком. В цьому контексті варто згадати про доступність сировини по адекватній ціні, а невідповідність цій передумові, виключає можливість досягнення відповідного рівня безпеки. Натомість, неприпустимо високі ціни можуть виникнути внаслідок відсутності сировини, що може бути так прямим наслідком недостатньої кількості інвестицій в інфраструктуру виробництва, переробки чи транспортування, як і поточних короткотермінових політичних, економічних подій, катастроф чи інших форсмажорних обставин. А це означає, що жодна система не може бути визнана повністю безпечною.

На довготерміновий ризик накладається доступ до паливної сировини на відповідному рівні, інфраструктура видобування, переробки, транспортування та дистрибуції, які надають можливість постачати і стратегічно розв'язувати загрози, які виникають, надають можливість забезпечити попит та зрівноважений економічний ріст. Серед довготермінових ризиків виокремлюють:

1. Геологічні - стосуються фізичного вичерпання покладів корисних копалин,

2. Технічні - охоплюють аварії систем, спричинені атмосферними умовами, недостатньою кількістю інвестицій чи загалом низькими потужностями енергетичної системи;

3. Економічні - містять коливання цін на ринках, що виникають 3 не зрівноваженого попиту та пропози- 
4. Геополітичні - складаються 3 наступних елементів: політичні конфронтації, війни, страйки та тероризм;

5. Навколишнього середовища - ополюють потенціальну загрозу та збитки, викликані катастрофами (витоки нафти, аварії ядерних реакторів та ін.) і викидів парникових газів в атмосферу.

В нинішньому десятилітті, одним 3 документів, який представляє стратегію $\mathrm{CC}$ та, зокрема Польщі як одного з членів цього Союзу, $є$ „Енергія 2020. Стратегія для конкурентоспроможного, зрівноваженого та безпечного енергетичного сектора" (2010), в якій основну увагу сконцентровано на п'яти основних пріоритетах:

- досягнення енергетичної ефективності в Свропі;

- створення справді інтегрованого ринку енергії;

- надання більших прав споживачам та отримання найвищого рівня безпеки і впевненості;

- зміцнення керівної ролі Свропи у сфері енергетичних технологій та інновацій;

- зміцнення зовнішнього виміру ринку енергії $\mathrm{CC}^{1}$.

Одночасно вказується на значення і масштаби викликів та проблем, які з'являються, звертається увагу на необхідності забезпечення безпеки поставок енергії, ефективного використання потенціалу, доступних цін та інноваційних розв'язань, тому вони $\epsilon, \ldots$,.кючовим чинником довготермінового зрівноваженого росту, створення робочих місць та якості життя" 2 . Ця мета повинна бути досягнута в рамках спільно реалізованої енергетичної політики Європейського Союзу.

Розвиток затверджених цілей разом 3 додатковими діями в довготерміновій перспективі були представлені в березні 2011 року в документі під назвою „План дій, який веде до переходу на конкурентоспроможну економіку з низьким рівнем викидів до 2050 р."3.

Конкретним виміром забезпечення енергетичної безпеки, як стандарту в Республіці Польща, є створення тримісячного стратегічного резерву запасів нафти і нафтопродуктів, а також 30-денного запасу - природного газу. Відповідальність, за дотримання цих норм, покладено на Агентство матеріальних резервів (пол. - Agencja Rezerw Materiałowych) Польщі, яке було створено на підставі закону від 29 жовтня 2010 року „Про стратегічні резерви" та підпорядковується відповідному міністру в справах енергетики. Згадане Агентство реалізує завдання, на основі законів, у сфері управління стратегічними резервами, а також накопичує і зберігає запаси нафти та нафтопродуктів, а також наглядає за обов'язковими запасами нафти і палив.

Завдання Агентства:

- збереження стратегічних резервів, у тому числі зберігання, проведення обміну чи заміни та проведення консерваційних робіт щодо стратегічних резервів, які зберігаються;

- виконання рішень відповідного міністра у справах енергетики, які стосуються створення, надання і ліквідації стратегічних резервів, згідно 3 правилами, визначе- ними законом про стратегічні резерви;

- ведення інвестиційної діяльності, пов'язаної 3 будівництвом чи модернізацією технічної інфраструктури утримання стратегічних резервів;

- купівля та утримання запасів агентства нафти i нафтопродуктів, згідно з правилами, визначеними законом про запаси нафти і нафтопродуктів, а також виконання інших обов'язків, які виникають 3 цього закону;

- контроль суб'єктів, яким передано на зберігання стратегічні резерви, на підставі договору зберігання;

- опрацювання проекту інформації про асортимент стратегічних резервів, їх кількість і вартість та їх фінансування, використання і розміщення;

- складення планів, інформації, процедур і звітів та інших документів, у сфері визначеній в законі чи інших юридичних актах;

- виконання інших завдань, визначених в законах чи в Програмі стратегічних резервів ${ }^{4}$.

На даному етапі Польща є однією з найменш залежних від імпорту енергетичної сировини держав Європейського Союзу. Перевагу надають їй найбільші в Європі поклади кам'яного вугілля (60 млрд. тон), а також, відносно менші, поклади бурого вугілля (23 млрд. тон $)^{5}$, натомість більшість нафти та природного газу Польща змушена імпортувати. Головним постачальником цих двох видів палива $є$ Росія, завдяки близькому географічному розташуванню та хорошій інфраструктурі експорту, яка надає можливість постачати нафту і природний газ не тільки до Польщі, але й на захід Свропи. Іншими торговими партнерами в енергетичній галузі, на долю яких припадає близько 30\%, є Німеччина, Білорусія, Чехія, Словаччина, Казахстан, Литва, Норвегія та Україна.

У випадку диверсифікації поставок природного газу Польща розглядає дві можливості:

1. Прокладення 1000-кілометрового трубопроводу 3 Норвегії до Польщі, який би надав можливість істотно вплинути на енергетичну залежність від Росії. Але 3 економічної точки зору, витрати пов'язані з будівництвом цього газопроводу та вартість норвезького газу, яка $€$ вищою ніж російського, а також поступове зменшення норвезьких покладів природного газу, звели нанівець в 2007 році пропозиції уряду Ярослава Качинського щодо будівництва цього газопроводу. Варто згадати, що вартість російського газу, протягом останніх років, поступово зростає. Приміром, в 2016 році Польща закуповувала в Росії газ в середньому по 165 USD за 1 тис. м ${ }^{3}$ природного газу, в 2017 році його вартість зросла на $20 \%$ до 197 USD за 1 тис. м³, в той час, як Німеччина в 2016 році платила за російський природний газ 170 USD за 1 тис. м $^{3}$, а в 2017 році його вартість зросла тільки на $8 \%$ до 192 USD за 1 тис. м $^{36}$.

2. Більш економічно обгрунтованим та таким, що в кінцевому результаті дає більші переваги, було будівництво терміналу для скрапленого газу в м. Свіноуйсцє,

\footnotetext{
${ }^{1}$ Energia 2020. Strategia na rzecz konkurencyjnego, zrównoważonego i bezpiecznego sektora energetycznego. Komisja Europejska. COM (2010) 639, Bruksela 2010 [Energy 2020. A strategy for competitive, sustaibable and secure energy], P. 7 [in Polish].

${ }^{2}$ Ibid., P. 23.

${ }^{3}$ Plan działania prowadzący do przejścia na konkurencyjną gospodarkę niskoemisyjną do 2050 r. Komisja Europejska. COM(2011) 112. Bruksela 2011 [A Roadmap for moving to a competitive low carbon economy in 2050], 17 p. [in Polish].

${ }^{4}$ Agencja Rezerw Materiałowych. Zadania [Material Reserves Agency. Works], URL: https://www.arm.gov.pl/index.php?dz=zadania [in Polish].

${ }^{5}$ „Bilans zasobów złóż kopalin w Polsce według stanu na 31.XII.2017 r.”. Państwowy Instytut Geologiczny [Balance sheet of mineral resources in Poland at 31.XII.2017], Polish Geological Institut, Warsaw, 2018, P. 8 [in Polish].

${ }^{6}$ Polityka gazowa PiS - drogo i wcale niebezpiecznie [PiS gas policy - expensive and not at all dangerous], URL: https://for.org.pl/pl/ a/6119,polityka-gazowa-pis-drogo-i-wcale-nie-bezpiecznie [in Polish].
} 
який потенційно мав отримувати природний газ з Близького Сходу, Норвегії та Алжиру. Ця інвестиція є більш безпечною, ніж будівництво потужної інфраструктури транспортування природного газу, яка могла б використовуватись тільки до моменту вичерпання покладів цієї сировини в одній 3 держав-постачальників. Натомість слабким елементом цієї інвестиції є те, що зріджений природний газ є дорожчим ніж російський газ.

11 грудня 2015 року, вперше в історії, в польський порт м. Свіноуйсцє прибув танкер Al Nuaman з 210 тис. $\mathrm{m}^{3}$ скрапленого природного газу, який здійснив поставку вантажу з катарського порту Ras Laffan. Загалом, в період 32015 по 2018 рр. газопорт в м. Свіоуйсцє прийняв 40 танкерів зі скрапленим природним газом з Катару, Норвегії та США, що надало можливість зменшити імпорт російського газу до 9 млрд. м ${ }^{3}$ В 2018 році Польща отримала морським шляхом 2,71 млрд. м ${ }^{3}$ скрапленого газу та 3,8 млрд. м ${ }^{3}$ власного видобутку. В перспективі, до 2020 року, поставки одного тільки катарського скрапленого газу фірмою Qatargas повинні скласти 2,7 млрд. $\mathrm{M}^{3}$, поступово збільшаться також поставки американського скрапленого газу, а станом на 2042 рік Польща планує отримувати понад 7,3 млрд. м скрапленого газу морським шляхом. Короткотерміновим чинником, який стримує цей процес є Ямальський контракт, підписаний в середині 90-тих років минулого століття, згідно з яким польський державний нафтогазовий оператор $\mathrm{PGNiG}$ повинен сплачувати Газпрому до кінця 2022 року близько 85\% від законтрактованого об'єму газу, незалежно від того отримуватиме його Польща, чи ні. Природний газ, в рамках цього контракту, постачається на неринкових умовах, тому Польща, в Стокгольмському арбітражному суді, протягом багатьох років веде спір з Росією ${ }^{7}$.

Досить вагомим чинником для енергетичної незалежності Польщі стало б будівництво атомних електростанцій. Основною перевагою атомної енергетики $є$ чисте повітря, чиста вода та грунт. Вона $є$ найдешевшим джерелом енергії, приміром 1 МВт енергії, що виробляють вітрові електростанції, коштує 228 доларів, вугільні - 155 доларів, а атомні - тільки 85 доларів. Будівництво атомних електростанцій зменшує також конкурентоспроможність установок, що працюють на базі відновлювальних джерел енергії, які належать до Greenpeace, інших „зелених” організацій та в значній мірі дотуються за рахунок держави.

Перевагами ядерної енергетики, в порівнянні 3 iншими видами енергії, $\epsilon$ висока тепловіддача ядерного палива (у 2 млн. разів більша, ніж нафти, і в 3 млн. разів більша, ніж вугілля), кращі економічні показники, менше забруднення довкілля. До того ж відпадає потреба використовувати кисень, якого на енергетичні потреби спалюється в 5 разів більше, ніж його споживають усі живі істоти. Крім того, запаси ядерного пального (якщо їх необхідно буде повністю використати) приблизно в 20 разів перевищують запаси всіх видів органічного палива.

Під час дискусій експертів, присвячених будівництву атомної електростанції в Польщі, противники цього розв'язання дуже часто аргументують свою позицію тим, що це збільшить залежність польської держави від імпорту джерел енергії (ядерного палива). Але в цьому аргументі є тільки частинка правди.

49\% покладів урану знаходиться на територіях стабільних, демократичних держав (Австралія, ПАР, Бразилія), що належать до Організації економічного співробітництва та розвитку, це на багато більше ніж у випадку вугілля (42\%), газу (10\%) та нафти (14\%), тому законтрактована купівля ядерного палива не несе із собою ризику, з яким має справу Польща у випадку імпорту вуглеводнів з Росії. Крім цього, в Польщі є власні поклади урану, а його збагачення, зі стабільними західними партнерами, не викликатиме непорозумінь.

Вперше, на території Польщі, уран почали видобувати під час Другої світової війни, а в промислових масштабах - починаючи з 1948 р. в п'яти копальнях, чотири 3 яких знаходились в Нижній Сілезії (Ковари, Копаліни (Клєтно), Радоньово та Копанєц), а одна - в Свєнтокшиських горах (Рудки). Сировину спочатку видобували 3 териконів залізної та мідної руди, а потім - з експлуатаційних гірничих виробок. Уран, який видобували, під конвоєм направляли до Радянського Союзу. Натомість, у зв'язку із низьким вмістом урану в уранових рудах, які видобувалися в Польщі, та, відповідно, економічною недоцільністю, експлуатацію останньої польської уранової шахти, в с. Ковари, припинено в 1973 році, а протягом 1948-1973 років, загалом в Польщі, видобули близько 800 тонн уранової руди.

За підрахунками науковців, поклади уранових руд на території Польщі складають близько 150 тис. тон, більшість 3 яких припадає на с. Райськ Підляського воєводства (понад 88 тис. тон) та Синкліну пшибалтицьку (10 тис. тон). Цієї кількості вистачить для роботи ядерного реактора потужністю 1000 MW протягом 900 років.

Вагомим чинником для розвитку атомної енергетики $є$ також те, що уран наявний також, як домішка, в покладах міді в районі м. Любін-Сєрошовіце, де щороку 17 тис. тон цієї радіаційної сировини потрапляє на терикони, хоча ця сировина могла б стати паливом для 10 ядерних реакторів загальною потужністю 10 тис. $\mathrm{MW}^{8}$.

Перша ядерна електростанція в Польщі повинна була бути збудована ще в середині 80 -тих років XX століття. В 1979 році підготовча група „Електротепловні Вибжеже", у складі 20 чоловік, розпочала роботу над проектами та документацією будівництва першої, в Польській народній республіці, атомної електростанції в селі Картошино на Жарновецькому озері. На території 400 гектарів в 1982 році розпочато будівництво, а Атомна Електростанція „Жарновець” стала візитною карткою тодішньої партійної комуністичної влади. До будівництва було залучено 70 польських підприємств, які виробляли турбіни, генератори, труби, а чотири ядерні реактори повинна була збудувати чехословацька фабрика „Шкода”. Але після вибуху, в 1986 році ядерного реактора в Чорнобилі, настрої в польському суспільстві радикально змінилися, а в 1989 році закінчились кошти на фінансування цього проекту, на той час, для завершення будівництва і запуску АЕС в Польщі, не вистачало тільки 300 млн доларів.

Уряд нового прем'єр-міністра Тадеуша Мазовецького, враховуючи протести екологів, незважаючи на те, що атомні реактори в Жарновцю були іншої генерації

\footnotetext{
${ }^{7}$ Spada udział importu gazu z Rosji. Rośnie LNG [The share of gas imports from Russia is falling. LNG is growing], URL: https://cnglng.pl/wiadomosci/Spada-udzial-importu-gazu-z-Rosji.-Rosnie-LNG,wiadomosc,9630.html [in Polish].

${ }^{8}$ Polskie złoża uranu. Nadzieja czy zagrożenie dla Polski i jej środowiska? [Polish uranium deposits. Hope or threat to Poland?], URL: http://wdolnymslasku.com/2018/08/16/polskie-zloza-uranu-nadzieja-czy-zagrozenie-dla-polski-i-jej-srodowiska [in Polish].
} 
ніж в Чорнобилі, в листопаді 1989 року вирішив призупинити будівництво польської АЕС, а у вересні 1990 року - повністю припинити це будівництво. Один 3 атомних реакторів було продано Фінляндії, де він досі працює на фінській атомній електростанції в м. Ловііса.

Враховуючи енергетичну безпеку держави, в січні 2009 р. уряд Польщі вирішив розпочати роботи над Програмою польської ядерної енергетики (РРЕЈ), метою якої був запуск в 2020 р. ядерної електростанції. Ухвалена 28 січня 2014 р., $з$ трьохрічною затримкою, урядом Програма містить детальну політику Польщі щодо ядерної енергетики на 2014 - 2030 роки. Заплановані витрати на будівництво ядерної електростанції в Польщі складають близько 75 млрд. польських злотих $(18,5$ млрд. євро). Локалізації, які розглядаються Програмі це Люб'ятово Копаліно та Жарновець.

В 2014 - 2016 роках проведено підбір технології та виконавця будівництва першого енергоблоку, але не обрано місця зберігання радіоактивних відходів. В результаті відсутності співпраці між урядом та фірмоюінвестором PGE EJ1, відповідальною за реалізацію завдань, пов'язаних 3 підготовкою та будівництвом першої ядерної електростанції в Польщі, станом на кінець вересня 2017 року, фірма-інвестор не виконала жодних зобов'язань, передбачених першим етапом Програми, які повинна була реалізувати до кінця грудня 2016 року. 3 огляду на це, уряд оголосив про пошук нового інвестора, що спричинить перенесення терміну здачу в експлуатацію першого реактора з 2024 на 2030 рік.

Хорошим способом на диверсифікацію джерел енергії є збільшення частки відновлювальних джерел в загальному використанні енергії, завдяки чому частка конвенціональних джерел зменшується, що спричиняє зменшення імпорту палива.

На фоні інших держав ЄС Польща є головним виробником газу, що походить з біомаси. Негативні сторони відновлювальних джерел енергії - висока собівартість ціни енергії в порівнянні з традиційними джерелами енергії. На ВДЕ необхідно виділяти дотації.

Проблемою польської енергетики, в найближчій перспективі, буде відсутність можливості досягнення середнього рівня ЄС-28 у сфері використання відновлювальних джерел енергії, який в Свропейському Союзі в 2010-2014 роках зріс з 20,1\% до 25,2\%. Незважаючи на поступовий ріст частки відновлювальних джерел енергії в економіці з 10,2\% до $12,7 \%$ в 2010-2015 роках, різниця між Польщею та ЄС-28 збільшувалася з кожним роком. Відповідне встановлення рівня отримання енергії з відновлювальних джерел енергії та конвенціональних джерел $є$ однією з передумов досягнення енергетичної безпеки більшості цивілізованих держав світу.

Трьома найважливішими нетрадиційними джерелами енергії в Польщі в 2015 р. були: тверде біопаливо, рідке біопаливо та енергія вітру. Їх частка у відновлювальних джерелах складала відповідно: 72,22\%, 10,78\% та $10,76 \%$. Решта альтернативних джерел енергії використовувалась в незначній мірі ${ }^{9}$.

Станом на 30.06.2017 р. приріст щорічних потужностей польських електростанцій, що використовують енергію з відновлювальних джерел, за період з 2010 по 2017 роки, складав в середньому близько 700 мегават. Необхідно згадати, що найбільша частка в прирості встановлених потужностей, в згаданий період, припадала на вітрові електростанції. Зниження темпів росту в 2017 р. можна пояснити змінами в законодавстві, що обмежили розвиток вітрової енергетики.

Польське товариство вітрової енергетики наводить дані, що якщо в 2016 р. в Польщі підключено до мережі нові вітрові ферми потужністю $1225 \mathrm{MBT}$, то в 2017 році їх було вже тільки $41 \mathrm{MBT}$, а в 2018 році $-15,7 \mathrm{MBT}^{10}$, що може яскраво свідчити про поступове зменшення зацікавленням вітровими фермами в Польщі. Варто також згадати про досвід інших європейських держав в галузі вітрової енергетики - безперечним лідером, завдяки своєму географічному розташуванню, є Данія, в якій працює близько 5 тисяч вітрових генераторів, що виробляють близько 48\% від всієї електроенергії в державі. Важливим чинником є також свідомість громадян Данії - понад 100 тис. громадян цієї держави, шляхом створення кооперативів, інвестували власні кошти в будівництво вітрових електростанцій. натомість Польща не має такого потенціалу в вітровій енергетиці, подібним чином складається ситуація 3 гідроелектростанціями.

Найпотужніша польська гідроелектростанція в місті Влоцлавек, що на Віслі, має потужність 162 МВт, що 8-10 разів менше в порівнянні з потужністю одного ядерного реактора на АEC, тому гідроенергетика не змозі вирішити питання енергетичної безпеки на рівні держави.

Деякі науковці, приміром проф. Ян Попчик зі Шльонської політехніки, переконує, що якщо інвестувати 10 мільярдів євро в термомодернізацію польських будинків та прибудинкові джерела енергії, а саме, сонячні електростанції та біогазові установки, то ефект був би значно більшим ніж в будівництво та запуск першого атомного енергоблоку в Польщі.

Економічні аспекти - протягом останніх десятиліть Польща характеризувалася високим рівнем покриття попиту на первинну енергію за рахунок власного видобутку сировини. Це виникало зі значних покладів вугілля на території держави та грунтування на ньому польської енергетики. Незважаючи на високі показники видобутку цієї сировини, відповідно до даних Головного Статистичного Управління Республіки Польща, ця держава була імпортером цього носія енергії. Причиною цього була відносно висока собівартість видобутку в порівнянні з закордонними аналогами. На високу собівартість польського вугілля впливає: - застаріла технологія та відсутність достатніх інвестицій в цьому напрямку; - високі витрати на видобуток, які складають більше $80 \%$ від ціни тони вугілля; - низька продуктивність працівників; - погана організація роботи (обладнання використовується в неповній мірі); - поступове зменшення легко доступних покладів цієї сировини. Продуктивність польських шахт в 2012 році складала близько 700 тон на одного працівника, в той час як в США цей показник складав 4500 тон. Для підтримки національного виробника, а саме, вуглевидобувного комплексу, уряд Польщі протягом багатьох років дотував цю галузь економіки.

Енергетична безпека Польщі може оцінюватись на підставі показника залежності від імпорту, який необхідно розраховувати відповідно до формули: Б = (Ic -

\footnotetext{
${ }^{9}$ Główny Urząd Statystyczny. Energia 2016 [Central Statistical Office. Energy 2016], P. 28 [in Polish].

${ }^{10} \mathrm{Gram} w$ zielone. Portal zielonej energii. Energia wiatrowa [I play green. Green energy portal. Wind energy ], 2019, URL: http:// gramwzielone.pl/energia-wiatrowa/34289/psew-nowoczesne-turbiny-to-energia-za-150-zlmwh [in Polish].
} 
- Ес)/Св x 100\%, де: Б - енергетична безпека, Ic - імпорт сировини; Ес - експорт сировини; Св - внутрішнє споживання. 3 огляду на це, в 2016 році, Польща була однією 3 найбільш незалежних держав $С \mathrm{C}, 3$ огляду на, що показник енергетичної безпеки складав $30 \%$, в тому час як середня ЄС була на рівні 53\%.

Важливим чинником $є$ факт того, що енергетична самодостатність не $\epsilon$ необхідною умовою для досягнення енергетичної незалежності. Ї̈і можна досягнути шляхом відповідної диверсифікації поставок необхідної сировини, що в свою чергу, мінімізує ризик залежності від постачальника. У випадку Польщі, головним постачальником нафти і газу, в згаданий період, була Росія. Тому необхідно з'ясувати, на скільки передбачуваним i безпечним постачальником відносно Польщі була ця держава. В цьому контексті варто згадати про припинення поставок газу Росією Україні в 2006 та 2009 роках, що спричинило зниження тиску в системі для інших держав. Для Росії газ $є$ політичним аргументом, ціна якого може встановлюватись окремо для кожної 3 держав-імпортерів. Нестабільність цін газу та нафти може стати причиною інфляції та зменшення виробництва і внутрішнього попиту в економіці ${ }^{11}$, що може викликати падіння економіки та дефолт.

В цьому контексті важливим є будівництво газопроводу Nord Stream 2. Цей проект має на меті будівництво газопроводу між Росією та Німеччиною через Балтійське море в обхід держав-транзитерів. Цей проект ставить під загрозу санкції, які були накладені на Росію та суперечить законодавству СС, згідно 3 яким одне підприємство не може бути відповідальним за транзит та видобуток сировини. Будівництво цього газопроводу є потенційною загрозою для газопроводу Ямал, який проходить через Польщу та призведе до втрати Польщею позиції країни-транзитера газу.

Висновки. Незважаючи на досить низькі показники залежності від імпорту, Польща в значній мірі змушена постачати газ та нафту з Росії. Ця залежність поступово зменшується за рахунок будівництва терміналів скрапленого газу та диверсифікації поставок енергетичної сировини. Починаючи з 1990 року рівень енергоємності промисловості поступово зменшується, незважаючи на це, протягом наступних десятиліть, Польща по- винна збудувати та запустити принаймні одну атомну електростанцію 34 енергоблоками для покриття попиту на електроенергію на внутрішньому ринку.

Oleg Sliusar. The state and prospects of Poland's energy security. The article analyzes the current state of energy security in Poland, points out the significant potential of nuclear power engineering, the state of development of power engineering on the basis of renewable energy sources, its economic components, and the impact of energy security on the state of the future and the prospects for the development of this industry. The analysis of this problem led to the use of the following research methods, among which the economic analysis made possible to study the cost of production of kilowatt energy supplied by power plants; the method of theoretical analysis combined with practical calculations made possible to establish the feasibility of building nuclear power plants in Poland, and also the need for further diversification of natural gas supplies to reduce dependence on the Russian Federation. Scientific novelty. For the first time, the nuclear potential of Poland and its dependence on this factor of the state's energy security are analyzed in detail. Conclusions. The analysis shows the necessity to build nuclear power plants to ensure sustainable development and energy security in Poland.

Key words: energy, energy security, nuclear energy, renewable energy sources, diversification of supplies.

Олег Слюсар - дочент кафедри сучасних іноземних мов та перекладу факультету історії, політології та міжнародних відносин Чернівецького національного університету імені Юрія Федьковича. В науковому доробку автора - 60 друкованих праць, 2 словники (1 - у співавторстві). Коло наукових інтересів: ономастика, методика викладання іноземних мов, енергетична безпека.

Oleg Sliusar - Associate Professor of the Department of Modern Foreign Languages and Translation Studies of the Faculty of History, Political Science and International Studies of Yuriy Fedkovych Chernivtsi National University. In the scientific heritage of the author - 60 published works, 2 dictionary (1 coauthored dictionary). Research interests: Onomastics, Teaching Methods of Foreign Languages, Energy Security.

Received: 09.04.2019

Advance Access Published: June, 2019

(C) O. Sliusar, 2019

\footnotetext{
${ }^{11}$ Księżopolski K.M. „Wpływ odnawialnych źródeł energii na bezpieczeństwo ekonomiczne Polski” [The impact of renewable energy sources on Poland's economic security], Odnawialne źródła energii w Polsce. Wybrane problemy bezpieczeństwa, polityki i administracji [Renewable energy sources in Poland. Selected problems of security, politics and administration], Warszawa, 2013, P. 17 [in Polish]
} 